\title{
Postprandial Hypoglycemia in Children after Gastric Surgery: Clinical Characterization and Pathophysiology
}

\author{
Andrew C. Calabria ${ }^{a} b$ Lawrenshey Charles ${ }^{a}$ Stephanie Givler ${ }^{a}$ \\ Diva D. De León ${ }^{a, b}$ \\ a Division of Endocrinology and Diabetes, The Children's Hospital of Philadelphia, and bepartment of Pediatrics, \\ Perelman School of Medicine at the University of Pennsylvania, Philadelphia, Pa., USA
}

\section{Established Facts}

- Dumping syndrome is a common complication in children after fundoplication, and unlike in adults, is most often characterized by postprandial hypoglycemia (PPH).

- In children with dumping syndrome, early hyperglycemia after a meal triggers an exaggerated insulin response resulting in $\mathrm{PPH}$.

- In children with dumping syndrome, postprandial plasma concentrations of GLP-1 are significantly higher than in control children.

\section{Novel Insights}

- In children with PPH, antagonism of the GLP-1 receptor with exendin-(9-39) blunts the insulin response, even in the presence of hyperglycemia, suggesting that the exaggerated insulin response to a meal is at least in part due to the effects of GLP-1 on the pancreatic $\beta$-cell.

- GLP-1 receptor antagonists may represent a potential avenue for the treatment of PPH.

\section{Key Words}

Postprandial hypoglycemia · Children · Gastric surgery ·

Dumping · GLP-1 · Exendin-(9-39) · Insulin · Fundoplication

\begin{abstract}
Background/Aims: Dumping syndrome is a common complication in children after fundoplication and other gastric surgeries and is characterized by postprandial hypoglycemia (PPH). Children with PPH have an exaggerated GLP-1 response to a meal with an exaggerated insulin surge and sub-
\end{abstract}

sequent hypoglycemia. We evaluated the role of GLP-1 in the pathogenesis of PPH by examining the effects of GLP-1 receptor blockade on glucose and insulin response to a meal. Methods: Six children with known PPH after surgery underwent a mixed meal tolerance test with/without the GLP-1 receptor antagonist exendin-(9-39) using an openlabel crossover design. Results: Average nadir plasma glucose concentration was $\geq 65 \mathrm{mg} / \mathrm{dl}$ in all treatment conditions; however, 3 out of the 6 subjects had a nadir plasma

ClinicalTrials.gov identifier: NCT01162499.

\section{KARGER}

E-Mail karger@karger.com www.karger.com/hrp (c) 2015 S. Karger AG, Base

$1663-2818 / 15 / 0852-0140 \$ 39.50 / 0$
Diva D. De León, MD

Division of Endocrinology and Diabetes The Children's Hospital of Philadelphia

3615 Civic Center Boulevard, Room 802A, Philadelphia, PA 19104 (USA)

E-Mail deleon@email.chop.edu 
glucose $<65 \mathrm{mg} / \mathrm{dl}$ during vehicle infusion, while only 1 out of the 6 had a nadir plasma glucose $<65 \mathrm{mg} /$ dl during infusion of exendin-(9-39). Exendin-(9-39) suppressed postmeal insulin concentrations when compared to vehicle, with a lower peak insulin concentration observed in the children who received $500 \mathrm{pmol} / \mathrm{kg} / \mathrm{min}$ of exendin-(9-39) (131.3 \pm $125.1 \mathrm{pmol} / \mathrm{l})$ compared to children who received $300 \mathrm{pmol} /$ $\mathrm{kg} / \mathrm{min}(231.1 \pm 153.4 \mathrm{pmol} / \mathrm{l})$ or vehicle $(259.7 \pm 120.2$ $\mathrm{pmol} / \mathrm{l})$. Gastric emptying was not different between groups. Conclusion: Our results suggest that the exaggerated insulin response to a meal is at least in part due to the effects of GLP-1 on the pancreatic $\beta$-cell and suggest that GLP-1 receptor antagonists may represent a potential avenue of treatment for children with PPH.

c) 2015 S. Karger AG, Basel

\section{Case Presentation}

A 3-year-, 2-month-old male with complicated medical history noteworthy for gastric pull-through surgery for tracheoesophageal fistula (TEF) at 14 months, presented to the emergency room with a plasma glucose of $28 \mathrm{mg} / \mathrm{dl}$ associated with neuroglycopenic symptoms including confusion and dizziness following a meal. He had one prior episode of documented hypoglycemia in the setting of a prior parvovirus infection. The child had a history of 6 seizures of unclear etiology in the 2 years following TEF repair. In the emergency room, he was given an intravenous bolus of dextrose, his plasma glucose normalized, and he returned to his baseline status. Because of the history of gastric surgery and his postprandial symptoms, he was suspected to have PPH. He underwent an oral glucose tolerance test, which revealed a peak plasma glucose concentration of $351 \mathrm{mg} / \mathrm{dl}$ at $30 \mathrm{~min}$ and a nadir plasma glucose concentration of $41 \mathrm{mg} / \mathrm{dl}$ at $120 \mathrm{~min}$ postglucose load. He was started on therapy with the alpha-glucosidase inhibitor acarbose $(25 \mathrm{mg}$ three times/day with meals) [1]. His plasma glucose concentrations improved with acarbose treatment and dietary modifications (avoidance of simple sugars; inclusion of protein-rich foods with complex carbohydrates). Despite these therapies, he has struggled with intermittent diarrhea, a known complication of acarbose, and intermittent hypoglycemia despite treatment. Figure 1 depicts a trace of his glucose profile over a week as recorded by continuous glucose monitoring system (Medtronic ${ }^{\circledR} \mathrm{iPro}^{\mathrm{TM}}$, Minneapolis, Minn., USA).

\section{Introduction}

Although described over 20 years ago [2, 3], most clinicians remain unaware of the risk of dumping syndrome (DS) after gastric surgery. In children, DS occurs more frequently as a complication of fundoplication surgery and is characterized by severe postprandial hypoglycemia $(\mathrm{PPH})$, also known as 'late dumping syndrome', that typ- ically occurs $1-3 \mathrm{~h}$ after a meal but without the significant gastrointestinal symptoms of 'early dumping' [1,4].

The true prevalence of DS in children is controversial; some studies report it as an infrequent complication [5, 6], while others estimate the frequency to be higher [7, 8]. This variability may be explained by differences in the definitions of DS and screening practices used to diagnose DS. Because symptoms of PPH may not be specific, our group has advocated for universal postoperative screening to detect PPH after fundoplication [9]. Following the institution of a postoperative surveillance plan in our neonatal intensive care unit, our group has shown that $24 \%$ of children who had undergone a fundoplication showed evidence of $\mathrm{PPH}$ [9]. Earlier identification of $\mathrm{PPH}$ may lead to earlier treatment and prevention of the effects of unidentified hypoglycemic events.

The typical response to an oral glucose tolerance test or a meal in children with $\mathrm{PPH}$ is characterized by early hyperglycemia and an exaggerated GLP-1 response, followed by an exaggerated insulin surge and subsequent hypoglycemia [10]. The classical view of the pathophysiology has been that rapid absorption of carbohydrates following a meal results in early hyperglycemia, which triggers the exaggerated insulin response. However, peak insulin concentrations after a meal are proportionally higher than the degree of hyperglycemia in some of these children [3]. We hypothesized that the exaggerated GLP1 response to a meal may at least in part be responsible for the postprandial hyperinsulinemia and subsequent hypoglycemia [10]. GLP-1 is a potent insulinotropic hormone secreted by intestinal L-cells after a meal. In addition to enhancing postprandial insulin secretion [11-13], GLP-1 has other actions that are complementary to the incretin effect, including inhibition of glucagon secretion [14, 15], hepatic glucose production $[16,17]$, gastric emptying [18, $19]$, and appetite [20, 21].

Under physiologic conditions, circulating plasma GLP-1 concentration is low, which has prompted speculation that circulating GLP-1 cannot fully explain the $\beta$-cell effects. However, in states where plasma GLP-1 concentrations are significantly elevated, as seen after gastric bypass surgery, the elevated concentrations are more clearly responsible for the effects on GLP-1 receptors in the $\beta$-cell [22]. In adults with $\mathrm{PPH}$ after gastric bypass surgery, increased GLP-1-stimulated insulin secretion has been shown to contribute significantly to the hyperinsulinemia [23] and blockade of the GLP-1 receptor by exendin-(9-39) prevents the hypoglycemia in these individuals [24]. Exendin-(9-39), a derivative of the nonmammalian peptide exendin- 4 , acts as a specific and 


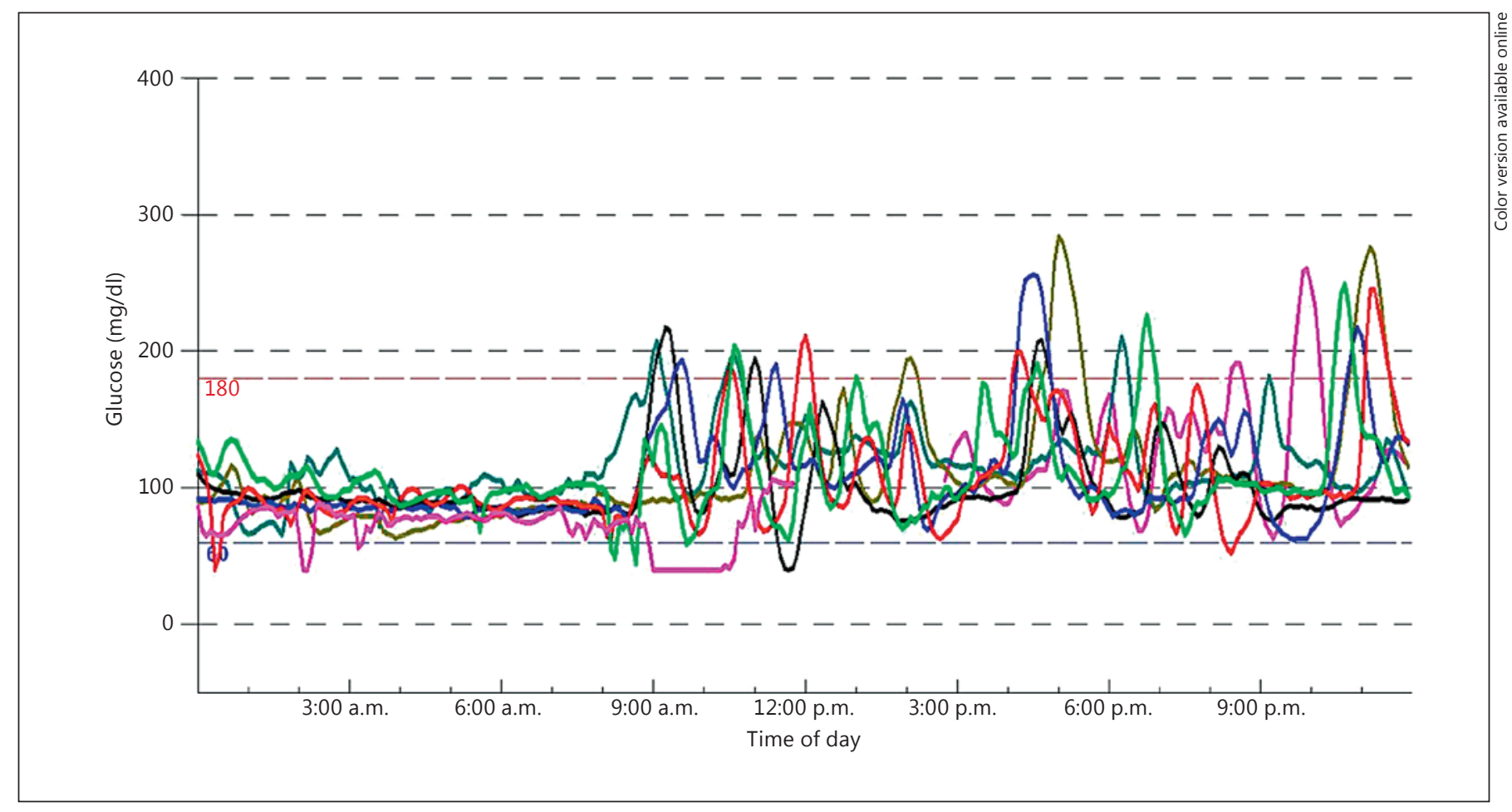

Fig. 1. Continuous glucose monitoring system profile for highlighted patient over the course of 1 week. Each different line represents a different day of the week. Profile shows significant daytime glucose fluctuations with significant hyperglycemia and intermittent hypoglycemia.

competitive antagonist of the GLP-1 receptor [25]. We have shown that exendin-(9-39) suppresses insulin and increases fasting plasma glucose in children and adults with congenital hyperinsulinemic hypoglycemia, and our group is currently evaluating the therapeutic potential of this peptide for this condition [26]. To examine the role of GLP-1 in the pathogenesis of PPH in children, we examined the effects of exendin-(9-39) on gastric emptying, as well as on the plasma glucose, insulin and glucagon responses to a meal in children with $\mathrm{PPH}$.

\section{Methods}

Children with PPH after fundoplication or gastric surgery aged 6 months to 18 years were recruited from the Division of Endocrinology and Diabetes at The Children's Hospital of Philadelphia. The study design was an open-label randomized complete crossover. Subjects were admitted to the inpatient CTRC unit and underwent 2 experiments on 2 consecutive days after an overnight 12 -hour fast. On one day, subjects received a continuous intravenous infusion of exendin-(9-39) for $1 \mathrm{~h}$ prior to consuming a standardized mixed meal and continued for a total of $4 \mathrm{~h}$. On the other day, subjects received a continuous intravenous infusion of normal saline. At time 0 , subjects consumed a mixed meal of PediaSure ${ }^{\circledR}$ (Abbott Nutrition, Columbus, Ohio, USA) $10 \mathrm{ml} / \mathrm{kg}$ (1 kcal/ml: $12 \%$ protein, $53 \%$ carbohydrate, $35 \%$ fat) by mouth or by gastrostomy tube. Because there was limited experience with exendin-(9-39) in children, we chose to start with a low dose. The first three subjects, including the subject described above, received a dose of exendin-(9-39) of $300 \mathrm{pmol} / \mathrm{kg} / \mathrm{min}(0.06 \mathrm{mg} / \mathrm{kg} / \mathrm{h})$ [Ex$9(300)]$. The dose was increased to $500 \mathrm{pmol} / \mathrm{kg} / \mathrm{min}(0.1 \mathrm{mg} / \mathrm{kg} / \mathrm{h})$ [Ex-9(500)] in the subsequent three subjects. Acarbose was withheld in all subjects who had been treated with it. Plasma glucose concentration was measured (Siemens Rapid Point 400 Blood Gas analyzer; Siemens Healthcare Diagnostics, Deerfield, Ill., USA) at $-60,0,10,30,60,90,120,150$, and $180 \mathrm{~min}$. Plasma insulin (ELISA, ALPCO Diagnostics, Salem, N.H., USA) and glucagon (RIA, Millipore, Linco Research, St. Charles, Mo., USA) concentrations were taken at $0,30,60,120$ and $180 \mathrm{~min}$. Plasma intact and total GLP-1 levels (ELISA, Millipore; Linco Research) were taken at 0, 10, 30, 60,120 , and $180 \mathrm{~min}$. Gastric emptying was evaluated using the paracetamol method. Paracetamol $(30 \mathrm{mg} / \mathrm{kg})$ Tylenol $^{\circledR}$ tablet (McNeil-PPC, Fort Washington, Pa., USA) was pulverized in a mortar and carefully mixed into the formula. The serum paracetamol concentrations were measured every $30 \mathrm{~min}$ using a colorimetric assay at $0,30,60,90,120,150$ and $180 \mathrm{~min}\left(\mathrm{ACET}^{\circledR}\right.$; Vitros Chemistry Products ${ }^{\mathrm{TM}}$; Ortho Clinical Diagnostics Inc., Johnson \& Johnson Health Care Systems, Piscataway, N.J., USA). The absorption of paracetamol is determined by the gastric emptying rate, and se- 
Table 1. Subject characteristics

\begin{tabular}{|c|c|c|c|c|c|c|}
\hline $\begin{array}{l}\text { Sub- } \\
\text { ject }\end{array}$ & $\begin{array}{l}\text { Age, } \\
\text { years }\end{array}$ & Surgery (age at surgery) & $\begin{array}{l}\text { Age at PPH } \\
\text { diagnosis }\end{array}$ & Feeding regimen & PPH treatment & $\begin{array}{l}\mathrm{PPH} \\
\text { frequency }\end{array}$ \\
\hline 1 & 8 & Nissen fundoplication (6 months) & 9 months & Oral only & Acarbose & Intermittent \\
\hline 2 & 18 & Nissen fundoplication (7 months) & 14 months & Both oral and gastrostomy & Feeding manipulations* & Intermittent \\
\hline 3 & 6 & Gastric pull-through (13 months) & 3 years & Oral only & Acarbose & Frequent \\
\hline 4 & 10 & Nissen fundoplication (4 months) & 3 years & Gastrostomy only & Acarbose & Intermittent \\
\hline
\end{tabular}

* Feedings were modified to decrease volume and slow rate of delivery.

rum concentrations correlate with gastric emptying of liquids [27]. The glycemic response is not influenced by co-ingestion of paracetamol. We measured the area under the curve (AUC) after the consumption of the formula, an accurate parameter of paracetamol absorption that is reportedly higher when gastric emptying is faster [27]. The study was approved by the Children's Hospital of Philadelphia Institutional Review Board, and informed consent was obtained from all participants or their parents.

\section{Results}

Six children aged 6-18 years (5 male) were recruited from the Division of Endocrinology and Diabetes at The Children's Hospital of Philadelphia and participated in the study (table 1). Five of the subjects had a Nissen fundoplication for severe GERD; one subject had a history of gastric pull-through surgery for TEF. All of the subjects were treated for $\mathrm{PPH}$, with either acarbose or feeding manipulations prior to enrollment.

Fasting plasma glucose concentrations were $79.8 \pm 3.1$ $\mathrm{mg} / \mathrm{dl}$ for vehicle; $83 \pm 2.6 \mathrm{mg} / \mathrm{dl}$ for $\operatorname{Ex}-9(300)$, and 89.7 $\pm 10.0 \mathrm{mg} / \mathrm{dl}$ for Ex-9(500). One hour after initiation of the infusion of vehicle and exendin-(9-39) (time 0), plasma glucose was $82.2 \pm 9.1 \mathrm{mg} / \mathrm{dl}$ for vehicle; $90 \pm 6 \mathrm{mg} / \mathrm{dl}$ for Ex-9(300), and $89.7 \pm 21.2 \mathrm{mg} / \mathrm{dl}$ for Ex-9(500). After consumption of the meal, plasma glucose concentration rose rapidly in all subjects but reached a greater peak in both exendin-(9-39) groups compared to vehicle [203.7 $\pm 50.5 \mathrm{mg} / \mathrm{dl}$ for vehicle; $240.3 \pm 21.4 \mathrm{mg} / \mathrm{dl}$ for Ex-9(300), and $231.7 \pm 23.0 \mathrm{mg} / \mathrm{dl}$ for Ex-9(500)]. Average nadir plasma glucose in all treatment conditions was greater than $65 \mathrm{mg} / \mathrm{dl}[66.7 \pm 10.9 \mathrm{mg} / \mathrm{dl}$ for vehicle; $66.3 \pm 14.5$ $\mathrm{mg} / \mathrm{dl}$ for Ex-9(300), and $74.3 \pm 7.4 \mathrm{mg} / \mathrm{dl}$ for Ex-9(500)] (fig. 2). Three out of the 6 subjects had nadir plasma glucose $<65 \mathrm{mg} / \mathrm{dl}$ during vehicle infusion, while only 1 out of the 6 had a nadir plasma glucose $<65 \mathrm{mg} / \mathrm{dl}$ during infusion of exendin-(9-39) and this subject received the lower dose of exendin-(9-39). Since plasma glucose nadir occurred in all groups at $180 \mathrm{~min}$ after the meal, which coincided with the end of the study period, it is not known if they would have continued to fall. AUC for plasma glucose was $21,715.9 \pm 3,597.8 \mathrm{mg} \cdot \mathrm{min} / \mathrm{dl}$ for vehicle; $22,192.5 \pm 4,784.7 \mathrm{mg} \cdot \mathrm{min} / \mathrm{dl}$ for Ex-9(300), and 25,207.1 $\pm 1,157.5 \mathrm{mg} \cdot \mathrm{min} / \mathrm{dl}$ for Ex-9(500).

At time 0, plasma insulin concentrations were undetectable for the vehicle and low exendin-(9-39) treatment conditions and $6.5 \pm 3.3 \mathrm{pmol} / \mathrm{l}$ for the high exendin-(9-39) dose. After a mixed meal, plasma insulin concentration increased in all subjects, reaching a peak at 30 min postmeal. Peak insulin concentration was lower in the high exendin-(9-39) dose group [259.7 $\pm 120.2 \mathrm{pmol} / 1$ for vehicle; $231.1 \pm 153.4 \mathrm{pmol} / \mathrm{l}$ for $\mathrm{Ex}-9$ (300), and 131.3 $\pm 125.1 \mathrm{pmol} / \mathrm{l}$ for Ex-9(500)]. By 120 min postmeal, plasma insulin concentration was still elevated in the vehicle treatment group, while it was suppressed in both exendin-(9-39) groups [87.8 $\pm 107.7 \mathrm{pmol} / 1$ for vehicle; 17.9 $\pm 20.8 \mathrm{pmol} / \mathrm{l}$ for $\mathrm{Ex}-9(300)$, and $20.8 \pm 19.5 \mathrm{pmol} / \mathrm{l}$ for Ex-9(500)]. By 180 min postmeal, insulin concentration returned to baseline in all groups (fig. 3). AUC for insulin was $19,435.4 \pm 10,392.6 \mathrm{pmol} \cdot \mathrm{min} / \mathrm{l}$ for vehicle; $14,695.85$ $\pm 12,662.9 \mathrm{pmol} \cdot \mathrm{min} / \mathrm{l}$ for $\mathrm{Ex}-9(300)$, and 9,058.5 \pm 7,562.7 $\mathrm{pmol} \cdot \mathrm{min} / 1$ for Ex-9(500).

At time 0, plasma glucagon concentration was higher in the Ex-9(500) treatment group $[60.3 \pm 22.1 \mathrm{pg} / \mathrm{ml}$ for vehicle; $52 \pm 12.1 \mathrm{pg} / \mathrm{ml}$ for $\mathrm{Ex}-9(300)$, and $74.7 \pm 8.5 \mathrm{pg} /$ $\mathrm{ml}$ for Ex-9(500)]. Plasma glucagon concentrations were higher in the Ex-9(500) group throughout the study with peak concentrations in all groups at $30 \mathrm{~min}$ postmeal [114 $\pm 50.1 \mathrm{pg} / \mathrm{ml}$ for vehicle; $127.5 \pm 75.7 \mathrm{pg} / \mathrm{ml}$ for Ex-9(300), and $145.7 \pm 33.6 \mathrm{pg} / \mathrm{ml}$ for $\mathrm{Ex}-9(500)]$. 


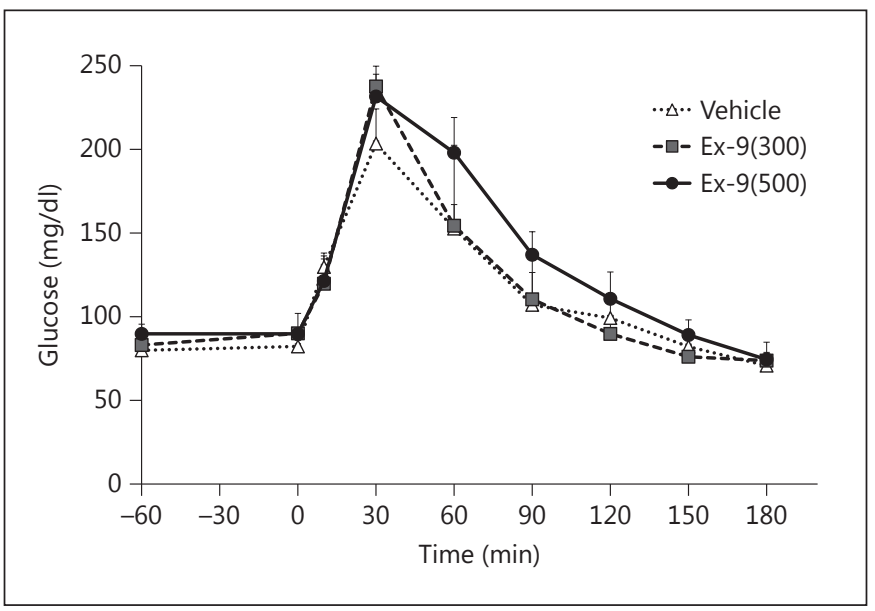

Fig. 2. Mean blood glucose concentration \pm SEM after a mixed meal during vehicle (triangle, dotted line), Ex-9(300) (square, dashed line), and Ex-9(500) (circle, solid line) infusion.

After 60 min of vehicle/exendin-(9-39) infusion (time 0 ), plasma intact GLP-1 concentration was slightly higher under the vehicle condition $[9.4 \pm 14.9 \mathrm{pmol} / \mathrm{l}$ for vehicle; $3.1 \pm 1.8 \mathrm{pmol} / \mathrm{l}$ for Ex-9(300), and $3.7 \pm 2.3 \mathrm{pmol} / \mathrm{l}$ for Ex-9(500)]. Intact GLP-1 peaked $30 \mathrm{~min}$ after the meal $[72.8 \pm 26.1 \mathrm{pmol} / \mathrm{l}$ for vehicle; $65.8 \pm 33.3 \mathrm{pmol} / \mathrm{l}$ for Ex9(300), and $75.2 \pm 5.8 \mathrm{pmol} / \mathrm{l}$ for Ex-9(500)] (fig. 4). A similar pattern was seen for total GLP-1 (data not shown).

The effect of exendin-(9-39) on gastric emptying was examined using the acetaminophen method. AUC for acetaminophen plasma levels were not different among the groups suggesting that exendin-(9-39) did not significantly alter gastric emptying during the study. AUC for acetaminophen was $3,436.6 \pm 465.2 \mu \mathrm{g} \cdot \mathrm{min} / \mathrm{l}$ for vehicle; $3,387.5 \pm 898 \mu \mathrm{g} \cdot \mathrm{min} / \mathrm{l}$ for Ex-9(300), and 3,742.8 \pm $124.3 \mu \mathrm{g} \cdot \mathrm{min} / \mathrm{ml}$ for Ex-9(500).

\section{Discussion}

Our results suggest that the exaggerated insulin response to a meal seen in children with PPH after gastric surgery is at least in part due to the effects of GLP-1 on the pancreatic $\beta$-cell, as the blockade of the GLP-1 receptor with exendin-(9-39) blunted the insulin response even in the presence of hyperglycemia. A larger study including more subjects would be necessary to establish the statistical significance of these observations.

The major limitation of our study, in addition to the small sample size, relates to the fact that none of the sub-

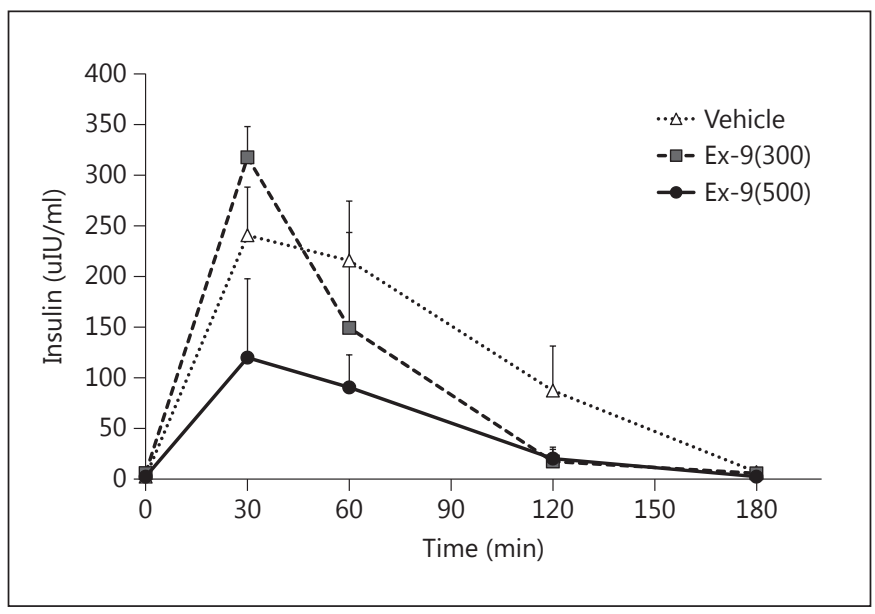

Fig. 3. Mean plasma insulin concentration \pm SEM after a mixed meal during vehicle (triangle, dotted line), Ex-9(300) (square, dashed line), and Ex-9(500) (circle, solid line) infusion.

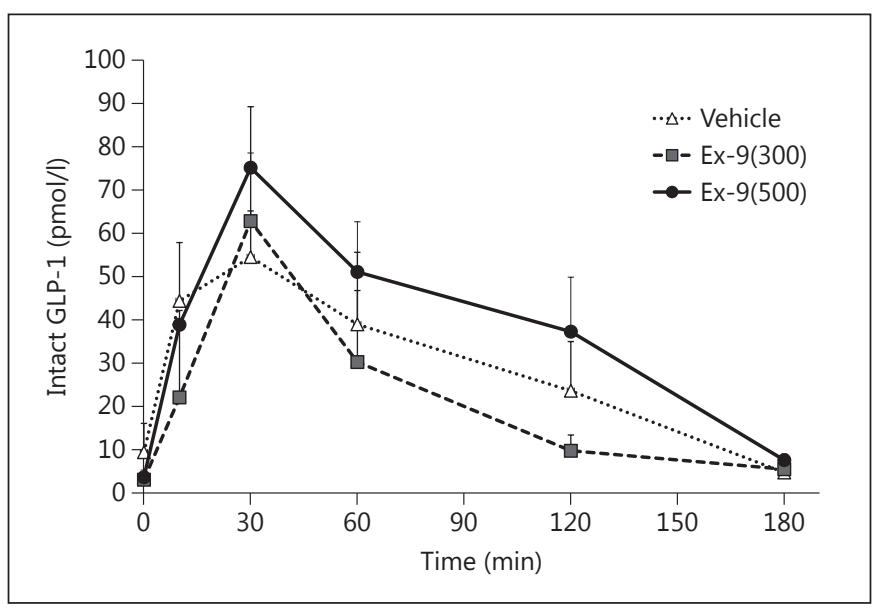

Fig. 4. Mean plasma intact GLP-1 concentration \pm SEM after a mixed meal during vehicle (triangle, dotted line), Ex-9(300) (square, dashed line), and Ex-9(500) (circle, solid line) infusion.

jects experienced significant hypoglycemia during the 3 -hour postmeal experimental period. It is not uncommon for episodes of late dumping after meals to be intermittent, so perhaps an oral glucose tolerance test would have been more appropriate as an experimental approach to reliably elicit PPH. While it is possible that at the time of recruitment the PPH had resolved in these children, the high plasma insulin concentration in response to the meal strongly argues against that conclusion. For safety reasons, we were limited on the dose of exendin-(9-39) 
that we could use in the study. However, it is clear from our limited data that the higher dose of exendin-(9-39) is more effective in inhibiting the exaggerated insulin response to a meal. In normal individuals, a dose of 300 $\mathrm{pmol} / \mathrm{kg} / \mathrm{min}$ exendin-(9-39) abolishes the effects of physiologic postprandial plasma levels of GLP-1 but not of supraphysiologic levels $[25,28]$. Thus, it is not surprising that a higher dose is required to block the effects of supraphysiologic levels of GLP-1 previously reported in children with $\mathrm{PPH}$ after fundoplication and observed in this study.

Despite these limitations, our work provides insights into the contribution of GLP-1 to the pathophysiology of this condition. Similarly, in adults with PPH after gastric bypass surgery, Salehi et al. [23, 24] showed that exendin-(9-39) inhibits the exaggerated insulin response and prevented hypoglycemia in individuals with PPH after gastric bypass surgery. These findings suggest that GLP-1 contributes significantly to the hyperinsulinemia and subsequent hypoglycemia, and strongly support the GLP1 receptor as a potential target for treatment of $\mathrm{PPH}$ after gastric surgery. This is an important consideration as current treatment options for children with PPH remain limited and suboptimal. A variety of therapies have been used with varying success, including uncooked cornstarch [29], pectin [8], octreotide [30], acarbose [3], and changes to the composition, volume, and rate of administration of feedings [31]. Many of the affected children continue to have severe hypoglycemia despite these interventions and require a regimen of continuous enteral feedings but continue to be at high risk of hypoglycemic events if feedings are abruptly stopped.

Close monitoring of postprandial glucose excursions is essential for preventing episodes of severe hypoglycemia that can cause neurologic damage. Our standard practice for home monitoring is to have parents monitor plasma glucose concentrations using a handheld glucose meter twice daily $90 \mathrm{~min}$ after meals or at other times if symptoms of hypoglycemia are noted. Recognizing the limitations of this strategy, continuous glucose monitoring systems may be used to provide increased monitoring capacity of glycemic excursions in those treated for $\mathrm{PPH}$ after fundoplication [32-34]. In our population, several patients have successfully worn the Medtronic ${ }^{\circledR} \mathrm{iPro}^{\mathrm{TM}}$ to monitor glycemic control of PPH for a period of 3-7 days to assess their glycemic control.

\section{Conclusions}

PPH remains a largely unrecognized complication of fundoplication and other gastric surgeries. While the exact incidence is unknown, many children will not have symptoms of $\mathrm{PPH}$, and we strongly advocate for universal screening in the immediate postoperative period in atrisk children. Early detection can lead to earlier treatment and prevention of brain damage from severe hypoglycemia. However, current treatment options, including acarbose, remain limited and have side effects, and despite these measures, many children will continue to have persistent PPH and may require continuous feeds or feeding manipulations. Our data show that blockade of the GLP1 receptor can blunt the insulin surge seen in children with PPH and implicates GLP-1 in this exaggerated insulin response. The possibility of new targeted therapies to decrease the effects of GLP-1 may improve the management of these children in the future.

\section{Acknowledgements}

This work was supported by grants from the National Center for Research Resources (UL1RR024134; D.D.D.L.), the Lester and Liesel Baker Foundation (D.D.D.L.), The Children's Hospital of Philadelphia Foerderer Award (D.D.D.L.), The University of Pennsylvania's Clinical and Translational Research Center's Junior Investigator Pilot Grant Program (A.C.C.), Research Fellowship Award from the Pediatric Endocrine Society (A.C.C.), and the National Institutes of Health/National Institute of Diabetes and Digestive and Kidney Diseases (T32-DK63688; A.C.C.).

\section{References}

1 Ng DD, Ferry RJJ, Kelly A, Weinzimer SA, Stanley CA, Katz LE: Acarbose treatment of postprandial hypoglycemia in children after Nissen fundoplication. J Pediatr 2001;139:877-879.

$>_{2}$ Villet R, Boureau M, Hayat P, Weisgerber G: Dumping syndrome, a serious complication of Nissen's operation: a report of four cases (author's translation). Chir Pediatr 1978;19: 269-273.

Postprandial Hypoglycemia in Children
Caulfield ME, Wyllie R, Firor HV, Michener W: Dumping syndrome in children. J Pediatr 1987;110:212-215.

4 Ralphs DN, Thomson JP, Haynes S, LawsonSmith C, Hobsley M, Le Quesne LP: The relationship between the rate of gastric emptying and the dumping syndrome. Br J Surg 1978; 65:637-641.
5 Gilger MA, Yeh C, Chiang J, Dietrich C, Brandt ML, El-Serag HB: Outcomes of surgical fundoplication in children. Clin Gastroenterol Hepatol 2004;2:978-984.

-6 Fonkalsrud EW, Ashcraft KW, Coran AG, Ellis DG, Grosfeld JL, Tunell WP, Weber TR: Surgical treatment of gastroesophageal reflux in children: a combined hospital study of 7467 patients. Pediatrics 1998;101:419-422. 
7 Bufler P, Ehringhaus C, Koletzko S: Dumping syndrome: a common problem following Nissen fundoplication in young children. Pediatr Surg Int 2001;17:351-355.

-8 Samuk I, Afriat R, Horne T, Bistritzer TJB, Vinograd I: Dumping syndrome following Nissen fundoplication, diagnosis, and treatment. J Pediatr Gastroenterol Nutr 1996;23:235240.

-9 Calabria AC, Gallagher PR, Simmons R, Blinman T, De Leon DD: Postoperative surveillance and detection of postprandial hypoglycemia after fundoplasty in children. J Pediatr 2011;159:597-601 e591.

10 Palladino AA, Sayed S, Katz LE, Gallagher PR, De Leon DD: Increased glucagon-like peptide-1 secretion and postprandial hypoglycemia in children after Nissen fundoplication. J Clin Endocrinol Metab 2009;94:39-44.

11 Drucker DJ: Biological actions and therapeutic potential of the glucagon-like peptides. Gastroenterology 2002;122:531-544.

12 MacDonald PE, El-Kholy W, Riedel MJ, Salapatek AM, Light PE, Wheeler MB: The multiple actions of GLP-1 on the process of glucose-stimulated insulin secretion. Diabetes 2002;51(suppl 3):S434-S442.

13 Holst JJ: Therapy of type 2 diabetes mellitus based on the actions of glucagon-like peptide-1. Diabetes Metab Res Rev 2002;18:430441.

14 Nauck MA, Kleine N, Orskov C, Holst JJ, Willms B, Creutzfeldt W: Normalization of fasting hyperglycemia by exogenous glucagon-like peptide-1 (7-36 amide) in type 2 (non-insulin-dependent) diabetic patients. Diabetologia 1993;36:741-744.

15 Orskov C, Holst JJ, Nielsen OV: Effect of truncated glucagon-like peptide-1 (proglucagon 78-107 amide) on endocrine secretion from pig pancreas, antrum and stomach. Endocrinology 1988;123:2009-2013.

-16 Hvidberg A, Nielsen M-B, Hilsted J, Orskov C, Holst JJ: Effect of glucagon-like peptide-1 (proglucagon 78-107 amide) on hepatic glucose production in healthy man. Metabolism 1994;43:104-108.
17 Larsson H, Holst JJ, Ahren B: Glucagon-like peptide-1 reduces hepatic glucose production indirectly through insulin and glucagon in humans. Acta Physiol Scand 1997;160:413422 .

18 Wettergren A, Schjoldager B, Mortensen PE, Myhre J, Christiansen J, Holst JJ: Truncated GLP-1 (Proglucagon 78-107-amide) inhibits gastric and pancreatic functions in man. Dig Dis Sci 1993;38:665-673.

19 Willms B, Wermer J, Holst JJ, Orskov C, Creutzfeldt W, Nauck MA: Gastric emptying, glucose responses, and insulin secretion after a liquid test meal: effects of exogenous glucagon-like peptide-1 (GLP-1)-(7-36) amide in type 2 (non-insulin-dependent) diabetic patients. J Clin Endocrinol Metab 1996;81:327332.

20 Flint A, Raben A, Astrup A, Holst JJ: Glucagon-like peptide-1 promotes satiety and suppresses energy intake in humans. J Clin Invest 1998;101:515-520.

21 Gutzwiller JP, Drewe J, Goke B, Schmidt H, Rohrer B, Lareida J, Beglinger C: Glucagonlike peptide-1 promotes satiety and reduces food intake in patients with diabetes mellitus type 2. Am J Physiol 1999;276:R1541-R1544.

22 Smith EP, An Z, Wagner C, Lewis AG, Cohen EB, Li B, Mahbod P, Sandoval D, Perez-Tilve $\mathrm{D}$, Tamarina N, et al: The role of beta cell glucagon-like peptide-1 signaling in glucose regulation and response to diabetes drugs. Cell Metab 2014;19:1050-1057.

23 Salehi M, Prigeon RL, D’Alessio DA: Gastric bypass surgery enhances glucagon-like peptide 1-stimulated postprandial insulin secretion in humans. Diabetes 2011;60:2308-2314.

24 Salehi M, Gastaldelli A, D’Alessio DA: Blockade of glucagon-like peptide 1 receptor corrects postprandial hypoglycemia after gastric bypass. Gastroenterology 2014;146:669-680 e662.

25 Schirra J, Sturm K, Leicht P, Arnold R, Goke B, Katschinski M: Exendin(9-39)amide is an antagonist of glucagon-like peptide-1(7-36) amide in humans. J Clin Invest 1998;101: 1421-1430.
26 Calabria AC, Li C, Gallagher PR, Stanley CA, De Leon DD: GLP-1 receptor antagonist exendin-(9-39) elevates fasting blood glucose levels in congenital hyperinsulinism owing to inactivating mutations in the ATP-sensitive K+ channel. Diabetes 2012;61:2585-2591.

27 Willems M, Quartero AO, Numans ME: How useful is paracetamol absorption as a marker of gastric emptying? A systematic literature study. Dig Dis Sci 2001;46:2256-2262.

28 Edwards CM, Todd JF, Mahmoudi M, Wang Z, Wang RM, Ghatei MA, Bloom SR: Glucagon-like peptide 1 has a physiological role in the control of postprandial glucose in humans: studies with the antagonist exendin 9-39. Diabetes 1999;48:86-93.

29 Borovoy J, Furuta L, Nurko S: Benefit of uncooked cornstarch in the management of children with dumping syndrome fed exclusively by gastrostomy. Am J Gastroenterol 1998;93: 814-818.

- 30 Lehnert H, Beyer J, Weber P, Krause U, Schrezenmeir J: Treatment of severe reactive hypoglycemia with a somatostatin analogue (SMS 201-995). Arch Intern Med 1990;150: 2401-2402.

- 31 Khoshoo V, Reifen RM, Gold BD, Sherman PM, Pencharz PB: Nutritional manipulation in the management of dumping syndrome. Arch Dis Child 1991;66:1447-1448.

- 32 Buscemi S, Mattina A, Genova G, Genova P, Nardi E, Costanzo M: Seven-day subcutaneous continuous glucose monitoring demonstrates that treatment with acarbose attenuates late dumping syndrome in a woman with gastrectomy for gastric cancer. Diabetes Res Clin Pract 2013;99:e1-e2.

-33 Ritz P, Vaurs C, Bertrand M, Anduze Y, Guillaume E, Hanaire H: Usefulness of acarbose and dietary modifications to limit glycemic variability following Roux-en-Y gastric bypass as assessed by continuous glucose monitoring. Diabetes Technol Ther 2012;14:736740 .

34 Hanaire H, Dubet A, Chauveau ME, Anduze Y, Fernandes M, Melki V, Ritz P: Usefulness of continuous glucose monitoring for the diagnosis of hypoglycemia after a gastric bypass in a patient previously treated for type 2 diabetes. Obes Surg 2010;20:126-129. 